\begin{tabular}{|l|l|l||}
\hline \multicolumn{2}{|c|}{ PublisherInfo } \\
\hline \hline PublisherName & $:$ & BioMed Central \\
\hline \hline PublisherLocation & $:$ & London \\
\hline \hline PublisherImprintName & $:$ & BioMed Central \\
\hline \hline
\end{tabular}

\title{
Radiodurans' rings and radioresistance
}

\begin{tabular}{|l|c|l||}
\hline \multicolumn{2}{|c|}{ ArticleInfo } \\
\hline \hline ArticleID & $:$ & 4676 \\
\hline \hline ArticleDOI & $:$ & $10.1186 /$ gb-spotlight-20030113-01 \\
\hline \hline ArticleCitationID & $:$ & spotlight-20030113-01 \\
\hline \hline ArticleSequenceNumber & $:$ & 28 \\
\hline \hline ArticleCategory & $:$ & Research news \\
\hline ArticleFirstPage & $:$ & 1 \\
\hline \hline ArticleLastPage & $:$ & 2 \\
\hline \hline & & RegistrationDate : 2003-1-13 \\
\hline ArticleHistory & $:$ & OnlineDate \\
\hline \hline ArticleCopyright & $:$ & BioMed Central Ltd2003-13 \\
\hline \hline ArticleGrants & $:$ & \\
\hline \hline ArticleContext & $:$ & 130594411 \\
\hline \hline
\end{tabular}




\section{Jonathan B Weitzman}

Email: jonathanweitzman@hotmail.com

The bacterium Deinococcus radiodurans has the remarkable ability to resist doses of ionising radiation many times higher than those that kill other organisms. In the January 10 Science Smadar Levin-Zaidman and colleagues at the Weizmann Institute of Science, Israel, report that the $D$. radiodurans genome has an unusual ring-like structure that may account for its radioresistance by restricting the diffusion of radiation-generated free DNA ends (Science 2003, 299:254-256). Scanning electron microscopy revealed that $D$. radioduranscells have a tetrad morphology with each quarter containing equal amounts of DNA (each contains a single copy of the bacterial genome). This compartmentalization suggests that DNA repair after radiation does not involve homologous recombination. The bacterial nucleoids adopt a toroidal morphology that presumably dictates a rigid structure, facilitating template-independent, error-free, end-joining of DNA breaks.

\section{References}

1. Resistance to radiation.

2. Science, [http://www.sciencemag.org]

3. Weizmann Institute of Science, [http://www.weizmann.ac.il] 